УДК 354.2

\title{
ЗАКОРДОННИЙ ДОСВІД ДЕРЖАВНОГО УПРАВЛІННЯ СФЕРОЮ ОСВІТНІХ ПОСЛУГ
}

\section{THE FOREIGN EXPERIENCE OF THE GOVERNANCE IN THE FIELD OF EDUCATIONAL SERVICES}

\author{
Самойлик Юлія Василівна \\ доктор економічних наук, профресор, \\ Полтавська державна аграрна академія \\ ORCID: https://orcid.org/0000-0003-1335-2331
}

\author{
Samoilyk Iuliia \\ Poltava State Agrarian Academy
}

\begin{abstract}
Стаття присвячена дослідженню проблем державного управління сферою освітніх послуг у різних країнах світу. Досліджено моделі державного управління сорерою освітніх послуг, які мають організаційний вплив на суспільні відносини у сорері освітніх послуг із застосування державно-владних повноважень та включають у себе цілеспрямоване розроблення, прийняття і реалізацію регулюючих і координуючих впливів. Наведено визначення десініції «державне управління сорерою освітніх послуг». Проаналізовано особливості державних політик більшості розвинених країн світу щодо сорери освіти. Встановлено, що найхарактернішим досвідом зарубіжних країн є оптимальне збалансування між державним регулюванням і автономією навчальних закладів, зокрема управління ними та їхнє фрінансування. Доведено, що автономія освітніх установ є тенденцією світового масштабу, проте в кожній країні виражається по-різному.
\end{abstract}

Ключові слова: державне управління, освітні послуги, освіта, реформа, розвиток.

Статья посвящена исследованию проблем государственного управления сфрерой образовательных услуг в разных странах мира. Исследованы модели государственного управления сферой образовательных услуг, имеют организационное влияние на общественные отношения в соере образовательных услуг по применению государственно-властных полномочий и включают в себя целенаправленное разработки, принятия и реализации регулирующих и координирующих воздействий. Приведены определения дефиниции «государственное управление сорерой образовательных услуг». Проанализированы особенности государственных политик большинства развитых стран мира относительно ссреры образования. Установлено, что характерным опытом зарубежных стран является оптимальное сбалансирование между государственным регулированием и автономией учебных заведений, в частности управления ими и их фринансирование. Доказано, что автономия образовательных учреждений является тенденцией мирового масштаба, однако в каждой стране выражается по-разному.

Ключевые слова: государственное управление, образовательные услуги, образование, реформа, развитие.

The article has been devoted to the study of public administration problems in the field of educational services in different countries. It has been established that the formation of the European Higher Education Area over 20 years involves joint cooperation between governments, higher education institutions and stakeholders, who should shape the higher education landscape. Models of public administration in the field of educational services, which have an organizational impact on public relations in the field of educational services for the use of public authority and include the purposeful development, adoption, and implementation of regulatory and coordinating influences, have been investigated. It is established that the choice of the state management model of educational services is related to the specifics of the country's socio-political conditions. The definition of "public administration of educational services" has been suggested. It has been found that radical changes and structural reforms in the field of modern education are taking place in all countries of the world. The peculiarities of the state policies of most developed countries in the field of education have been analyzed. It is established that the most characteristic experience of foreign countries is the optimal balance between state regulation and autonomy of educational institutions, in particular their management and financing. It has been proved that the autonomy of educational institutions is a global trend, but in each country it is expressed differently. It has been established that in European countries the introduction of democratic state and public management of education is relevant, which is determined by the constitutional and legislative norms of the functioning of the education sphere. It has been proved that, unlike American universities, European 
ones have less autonomy and, consequently, less freedom. It has been found that European universities rely on government agencies and American universities on public ones, because the US education sector is the responsibility of the state government, not the federal government. The main priorities are proposed: orientation of education on comprehensive development of personality and versatile financial support of educational institutions.

Keywords: public administration, educational services, education, reform, development.

Постановка проблеми. Освіта виступає державним пріоритетом, а її конкурентоспроможність $€$ індикатором успіху будь-якої країни. Вагомою передумовою збалансованого розвитку вітчизняної економіки є покращення рівня якості освітніх послуг і посилення конкурентних позицій випускників на ринку праці як в Україні, так і за її межами. Оскільки умови для подальшого розвитку освіти безпосередньо створює держава, то певний вид діяльності органів держави, що носить виконавчий та розпорядчий характер вважається державним управлінням сорерою освітніх послуг. Існують певні моделі державного управління сорерою освітніх послуг, які: по-перше, мають організаційний вплив на суспільні відносини у сорері освітніх послуг із застосування державно-владних повноважень; по-друге, включають у себе цілеспрямоване розроблення, прийняття і реалізацію регулюючих і координуючих впливів.

Аналіз останніх досліджень і публікацій. Аналіз, як закордонних, так і вітчизняних джерельних баз щодо наукових напрацювань 3 питань державного управління сферою освітніх послуг свідчить про те, що сучасне реформування вітчизняної системи надання освітніх послуг має ключову роль. Так, проблемні питання пов'язані із державним регулюванням системи освіти в Україні у своїх працях висвітлювала С.В. Григанська [9], державно-управлінський аспект ресрормування освіти в Україні досліджували Н.Г. Протасова, В.І. Луговий і Ю.О. Молчанова [3], загальні питання удосконалення державного управління вищою освітою в контексті європейської інтеграції І.М. Сікорська [4].

Виділення невирішених раніше частин загальної проблеми. У цілому науковці досліджуючи зарубіжний досвід акцентують увагу на загальних питаннях управління змінами в системі освіти різних країн світу. Проте недостатньо вивченими залишаються особливості державного управління сфрерою освітніх послуг.

Формулювання цілей статті (постановка завдання). Узагальнення закордонного досвіду державного управління сфрерою освітніх послуг.

\section{Виклад основного матеріалу дослід-} ження. Кардинальні зміни і структурні ресрорми в галузі сучасної освіти відбуваються в усіх країнах світу. Варто відзначити, що у травні 2018 року в Парижі відбулася Конференція міністрів освіти Європейського простору вищої освіти (The Fifth Bologna Policy Forum) у якій взяли участь європейські країни-члени Болонського процесу, представники інших країн, а також делегації від різних організацій світу [1]. На цьому фрорумі було ухвалено програмний документ «Паризьке комюніке, 25 травня 2018 року», у якому зазначено про невідкладне рішення щодо побудови Європейського простору вищої освіти (ЄПВО) впродовж наступних 20 років. На європейському рівні узгоджуються цілі та політика ЄПВО, які потім запроваджуються в національних освітніх системах і закладах вищої освіти [1]. Модель такого простору передбачає спільну співпрацю між урядами, закладами вищої освіти і стейкхолдерами, які й повинні сорормувати ландшафрт вищої освіти. Результатом таких зусиль стане широкомасштабна студентська мобільність, повна прозорість системи вищої освіти, а головне підвищення рівня якості освітніх послуг за допомогою діджіталізації.

Станом на 2020 рік до Європейського простору вищої освіти уже входять 48 державчленів, котрі приєдналися до Болонського процесу $[1 ; 2]$. Сама оцінка національних систем вищої освіти 50-ти країн світу щорічно відображається в рейтингу «The Universitas 21» (U21), який служить орієнтиром для урядів країн, освітніх установ і різного кола осіб [2].

Проте, не зважаючи на всі структурні перетворення, особливим і провідним видом профресійної діяльності залишається державне управління сорерою освітніх послуг, котре ґрунтується на законах та інших нормативних актах і планомірно впливає на цю сореру 3 метою її подальшого розвитку.

Науковці визначають дефініцію «державне управління сфрерою освітніх послуг » як цілеспрямовану діяльність щодо створення організаційних, правових, кадрових, соціально-прогностичних, педагогічних, матеріально-срінансових та інших умов, необхідних для оптимального 
фрункціонування і розвитку, реалізації мети, здійснення переходу в якісно новий стан [3, с. 9]. Сам вибір моделі державного управління освітніми послугами пов'язаний зі специфрікою соціально-політичних умов країни.

В Італії, Великобританії та Швейцарії фрункціонує дворівневе управління, засноване на поєднанні централізованого і місцевого. В Австрії, Нідерландах, Швеції діє трирівнева система управління освітою, що поєднує централізоване управління 3 регіональним і місцевим. У Німеччині та Італії велику роль в управлінні освітою відіграють місцеві органи влади. У Франції централізованою переходять до її децентралізації освіти [4, с. 38].

Заслуговує на увагу досвід Швеції показує, що ресрормування багаторівневої системи навчальних закладів стало соціально-орієнтованою політикою держави. Так, на протязі 2011-2012 років було здійснено низку радикальних перетворень у напрямах підвищення рівня: по-перше, соціального статусу профресії викладача/вчителя; по-друге, професійного розвитку; по-третє, успішності навчання споживачів освітніх послуг. Окреслені реформи і зміни призвели до покращення професійної підготовки шведської молоді [5, с. 87]. У Швеції загальні цілі та напрями роботи навчальних закладів визначаються на рівні держави і закріплені в Законі про освіту (2011р.), котрий включає базові принципи і положення [5, с. 91-92].

Останнім часом в європейських країнах актуальним $€$ впровадження демократичного державно-громадського управління освітою, яке визначається конституційно-законодавчими нормами фрункціонування сфрери освіти. У документах Ради Європи наголошується про те, що в основі децентралізації систем освіти закладено ідеї та цінності ринкової економіки [6, с. 194]. Так, у більшості розвинених країн світу державна політика щодо сорери освіти реалізується спеціально створеними центральними органами державного управління:

- США - міністерством освіти (автономія навчальних закладів $€$ найважливішим критерієм під час акредитації);

- Японії - міністерством освіти, науки і культури;

- Великобританії - міністерством освіти і науки;

- Франції - міністерством національної освіти [6, с. 195];

- ФРН - фредеральним міністерством науки і освіти;

- Швейцарії - федеральним управлінням освіти і науки департаменту внутрішніх справ та федеральне управління промисловості, ремесел і праці фредерального департаменту управління державними ресурсами тощо [6, с. 197];

- Польщі - міністерство національної освіти і міністерства науки та вищої освіти [7, с. 101; 8].

В Японії, США, ФРН і Скандинавських країнах органи управління в регіонах інтегрують плани розвитку освіти в плани регіонального економічного розвитку. Паралельно 3 управлінськими структурами, але в тісному зв'язку 3 ними в багатьох зарубіжних країнах функціонують координаційні органи, що вирішують важливі завдання з управління навчальними закладами. У США - координаційні ради на рівні штатів; у ФРН - постійна консреренція міністрів земель; у Франції - Національна рада освіти і наукових досліджень; у Великобританії - Комітет віце-канцлерів і ректорів університетів тощо [9].

Найхарактернішим досвідом зарубіжних країн $€$ оптимальне збалансування між державним регулюванням і автономією навчальних закладів, зокрема управління ними та їхнє фрінансування. На часі автономія освітніх установ $€$ тенденцією світового масштабу, але в кожній країні виражається по-різному.

В Нідерландах освітня автономія пов'язана із питаннями фрінансування, а саме існує переконання в тому, що для управління навчальними закладами ефективніше використовувати ринкові механізми ніж державні. Щодо якості освіти, то освітні установи Нідерландів декларують її як власні завдання і обов'язки, а інспекторські служби обмежують свою діяльність оцінюванням загальних досягнень школи.

Ринок і конкуренція є основними орієнтирами удосконалення освіти у Великобританії. Політика уряду зводиться до того, що освітні установи повинні: від держави отримувати фрінансування на навчальну діяльність і освітні послуги за контрактами; більше покладатися на різні джерела доходів і зменшувати залежність від державного фрінансування.

Автономія освітніх установ Франції обмежується великою кількістю підзаконними актами, ухвалами уряду і розпорядженнями. Згідно статистичних даних у Франції кількість вчителі в 1,5-2 рази перевищує середні показники країн $€ C$. Також особливістю фрранцузької освіти $€$ те, що вона має особливий розподіл на цикли, існує власна система дипломів і ступенів [6, с. 197; 7]. Державне регулювання здійснюється через укладання контрактів (договорів) між освітніми установами Франції і органами державного управління. У таких договорах фріксуються зобов'язання вищих закладів освіти перед державою у 
ссрері освіти і зобов'язання держави перед ними, зокрема створення викладацьких посад і срінансування [6, с. 197; 7].

У Швейцарії діє 26 освітніх програм, а на рівні держави організація й управління освітою децентралізовані, а на рівні суб'єктів фредерації (кантонів) - централізовані. Відповідно в Німеччині існує аналогічна ситуація.

Органи публічного управління Польщі рефрорми розпочинали зі ссрери надання освітніх послуг населенню. Представниками урядової адміністрації на місцях $€$ куратори освіти, котрі належать до середнього рівня державного управління освітою. Куратор, у свою чергу, координує педагогічні інновації та аналізує змістовну діяльність вузів, відповідає за якість освіти у своєму воєводстві.
Висновки. Таким чином, огляд наукових публікацій з обраної проблематики дозволяє сорормулювати висновки про те, що на відміну від американських вузів, європейські мають меншу автономію, а відповідно і менше свободи. У своїй діяльності європейські вузи опираються на державні структури, а американські - на громадські, бо сореру освіти США віднесено до компетенцій органів управління штатів, а не фредерального уряду.

Отже, сучасна вітчизняна система державного управління сфрерою освітніх послуг повинна стати державно-громадською і розвиватися за найкращими світовими зразками. Основними пріоритетами повинні стати: орієнтація освіти на всебічний розвиток особистості та різнобічна фрінансова підтримка навчальних закладів.

\section{СПИСОК ВИКОРИСТАНИХ ДЖЕРЕЛ:}

1. Паризьке Комюніке - 2018: створено Європейський простір вищої освіти / Національна академія педагогічних наук України. URL: http://naps.gov.ua/ua/press/about_us/1492/

2. U21 Ranking of National Higher Education Systems. URL: http://www.universitas21.com/article/projects/ details/152/u21-ranking-of-nationalhigher-education-systems (дата звернення: 10.03.2021).

3. Рефрормування освіти в Україні: державно-управлінський аспект : навчально-наукове видання / Н.Г. Протасова, В.І. Луговий, Ю.О. Молчанова та ін.; за заг. ред. Н.Г. Протасової. Київ; Львів : НАДУ, 2012. 456 с.

4. Сікорська І.М. Удосконалення державного управління вищою освітою в контексті європейської інтеграції : автореф. дис. ... канд. наук з держ. упр. : 25.00.02. Донец. держ. ун-т управління. Донецьк, 2006. 21 с.

5. Карпенко О.В., Вербова В.В. Освітні послуги в Швеції: досвід для України. Педагогіка і психологія. Вісник АПН України. 2013. № 2. С. 87-94.

6. Бабічев А.В. Зарубіжний досвід із питань управління змінами в системі вищої освіти. Теорія та практика державного управління. 2017. Вип. 2. С. 192-200.

7. Edukacja w gmsnie, powsacie iwojewodztwie: zwzorami regulamsnow I uchwal / red. t. Agata Galuska, Wieslav Misztal, Pawel Stanczyk; Federacja Zwsazkow I Stowarzyszen Cmin I Powiatow RP. Centrum Prawa Miejscowego. Krakow : Fundacja Rozwoju Samorzadnosci I Prasy Lokalnej, 1999. $108 \mathrm{~s}$.

8. Університети та ВН3 Польщі. Моја Edukacja - навчання в Польщі від 17 березня 2018 р. URL: https://mojaedukacja.com/universytety (дата звернення: 10.03.2021).

9. Григанська С.В. Державне регулювання системи вищої освіти в Україні : автореф. дис. ... канд. наук 3 держ. упр. : 25.00.02. Класичний приват. ун-т. Запоріжжя, 2008. 20 с.

\section{REFERENCES:}

1. Paris Communique - 2018: the European space of higher education was created / Natsionalna akademiia pedahohichnykh nauk Ukrainy. Available at: http://naps.gov.ua/ua/press/about_us/1492/

2. U21 Ranking of National Higher Education Systems. Available at: http://www.universitas21.com/article/ projects/details/152/u21-ranking-of-nationalhigher-education-systems (accessed 10 March 2021).

3. Reformuvannia osvity v Ukraini: derzhavno-upravlinskyi aspekt: navchalno-naukove vydannia [Reforming education in Ukraine: state-administrative aspect]: educational-scientific edition / N.G. Protasova, V.I. Lugovyi, Yu.O. Molchanov and others (2012); for general ed. N.G. Protasova. Kiev; Lviv: NAPA, 456 p.

4. Sikorskaya I.M. (2006) Udoskonalennia derzhavnoho upravlinnia vyshchoiu osvitoiu $v$ konteksti yevropeiskoi intehratsii [Improving public administration of higher education in the context of European integration]: author's ref. dis. ... cand. Sciences of the state. man.: 25.00.02. Donets. State University of Management. Donetsk, $21 \mathrm{p}$.

5. Karpenko O.V., Verbova V.V. (2013) Osvitni posluhy v Shvetsii: dosvid dlia Ukrainy [Educational services in Sweden: experience for Ukraine]. Pedahohika i psykholohiia. Visnyk APN Ukrainy [Pedagogy and psychology. Bulletin of the Academy of Pedagogical Sciences of Ukraine], no. 2, pp. 87-94. 
6. Babichev A.V. (2017) Zarubizhnyi dosvid iz pytan upravlinnia zminamy v systemi vyshchoi osvity [Foreign experience in managing change in higher education]. Teoriia ta praktyka derzhavnoho upravlinnia, vol. 2, pp. 192-200.

7. Edukacja w gmsnie, powsacie iwojewodztwie: zwzorami regulamsnow I uchwal / red. t. Agata Galuska, Wieslav Misztal, Pawel Stanczyk; Federacja Zwsazkow I Stowarzyszen Cmin I Powiatow RP (1999) Centrum Prawa Miejscowego. Krakow: Fundacja Rozwoju Samorzadnosci I Prasy Lokalnej.

8. Universities and universities of Poland. Moja Edukacja - study in Poland from March 17 (2018). Available at: https://mojaedukacja.com/universytety (accessed 10 March 2021).

9. Griganskaya S.V. (2008) Derzhavne rehuliuvannia systemy vyshchoi osvity v Ukraini [State regulation of the higher education system in Ukraine]: author's ref. dis. ... cand. sciences of the state. manag.: 25.00.02. Classic private. un-t. Zaporozhye, 20 p. 